\title{
Some Helminth Parasites of Gharial from Chitwan National Park, Nepal
}

\author{
Prakash Mani Kumal and Mahendra Maharjan \\ Central Department of Zoology, Tribhuvan University, Kathmandu Nepal \\ e-mail:prakanshu_mani96@yahoo.com
}

\begin{abstract}
A study on helminth parasites on captive gharial (Gavialis gangeticus) was conducted during July-December 2012 at Gharial Breeding Centre, Kasara, Chitwan National Park to isolate, identify and find out their prevalence. Dead gharial hatchlings were collected directly from the centre in fresh and frozen conditions. Out of 85 samples examined, 40 samples $47.06 \%$ as prevalence rate of helminth parasites. During the study three helminth parasites were first reported from the gharials of Nepal; Pentastomid (Sebekia sp.), Capillarioids and Ascaridoids. The dead hatchlings were found to be infected with Pentastomid (41.17\%), Ascaridoids (7.05\%), Capillarioids (1.17\%), Proctocaecum gairhei (3.52\%) and Exotidendrium sp. (36.47\%). In the month of December helminth parasites showed highest prevalence; Sebekia sp. (100\%) and Proctocaecum gairhei (75\%) and Exotidendrium sp. (100\%) and the lowest prevalence in the month of July; Sebekia sp. (4\%), Capillarioids (4\%) and Exotidendrium sp. (8\%).
\end{abstract}

Key words: gharial, helminth parasites, pentastomid, Chitwan National Park

\section{Introduction}

The gharial (Gavialis gangeticus) is a large fresh water crocodilian and only the surviving species belonging to the subfamily Gavialinae. It is found in Northern Indian subcontinent in river drainages of India, Pakistan and Nepal. Gharials have elongated and narrow snout and jaws, which are provided with many interlocking, sharp and razor like teeth. The body is provided with highly developed laterally flattened tail with webbed rear feet for swift movement in fast flowing water habitat. Their ventral scales are provided with highly developed sensory pits. The sexual dimorphism is distinct. The male has bulbous growth on the tip of snout while it is absent in female.

Gharials at captive breeding centre have very high mortality rate. Their major helminth para-sites so far known are Dujardiascaris woodlandi, Gedoelstascaris gavialidis, Multicaecum agile, Typhlophorus lamellaris, Micropleura vivipara, Crocodilicola gavialis, Exotidendrium sp., Harmotrema sp., Neodiplostomum gavialis, Proctocaecum dorsale, Proctocaecum gairhei, Subtriquetra megacephala and Subtriquetra shipleyi (Sprent 1977, Linstow 1906, Narain 1930, Junker \& Boomker 2006).

Gharial conservation began in Nepal with the help of Frankfurt Zoological Society which involves collection of wild eggs and is bred in the breeding center. The juveniles are released in different rivers of Nepal. The hatchlings are only fed with small sized fishes of different species and no such types of medicines are provided to them against any kind of diseases.

So, due to the lack of medicines and properly treated fishes they are prone to various types of helminthic infections which cause serious pathological as well as physiological disorders to them. So, helminthic infections can negatively affect the gharials at captive form and it demands for regular and systematic parasitological research. 


\section{Methodology}

From July to December of 2012, a total 85 dead gharial hatchlings were collected from Gharial Breeding

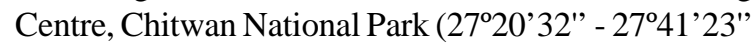

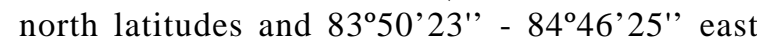
longitude) on the permission Department of National Park and Wildlife Conservation (DNPWC) of Nepal and the above centre. The samples were kept in sterile plastic bags and were transported to the nearest veterinary lab camped at Buffer Zone nearby Sauraha, Chitwan. The samples were dissected as described by Huchzermeyer (2003). The abdominal cavity was inspected thoroughly and various visceral organs were exposed and kept in separate watch glasses containing normal saline. Various parts of intestinal scraps were observed under microscope. Lungs and liver were teased for the presence of helminthes. Similarly, the fecal samples were also tested using both sedimentation techniques and floatation methods. The measurements of eggs were taken in micrometer and photographs were taken through microscope. The helminthes were preserved in $70 \%$ ethanol for further identifications by making permanent slides.

The nematodes were kept in lacto phenol for half an hour and mounted in glycerine. Thus permanent slide were prepared.

The trematodes were pressed between large sized cover slip and tied with rubber band and were left in alcohol formalin acetic acid solution for 24 hours. The fixed trematodes were gently removed and washed in distilled water. Then the trematodes were run in alcohol series and permanent slides were prepared. After $70 \%$ alcohol series they were stained with Gower's stain and finally mounted over DPX.

The pentastomid were directly observed under microscope after simple staining with Gower's stain and permanent slide were also prepared following similar method as followed for trematodes. The specimens have been deposited in helminthological collection of Tribhuvan University, Central Department of Zoology, Kirtipur, Kathmandu.

\section{Results and Discussion}

Out of 85 samples examined 40 samples were found to be positive contributing $47.06 \%$ as overall prevalence of helminthic infections. Out of the total helminth parasites recovered from different body parts, five types of helminthes were identified and remaining two helminths were left unidentified. Among the identified helminths, Sebekia sp. (41.17\%) and Exotidendrium sp. (36.47\%) were the highest prevalent ones followed by Ascaridoids (7.05\%), Proctocaecum gairhei $(3.52 \%)$ and finally the Capillarioids (1.17\%) infecting the captive gharial hatchlings at the Gharial Breeding Center, Kasara, Chitwan National park (Table1).

Table 1. General prevalence of helminth parasites in gharials

\begin{tabular}{l|l|c}
\hline S.N. & Endoparasites & Frequency (percentage) $(\mathbf{n}=\mathbf{8 5})$ \\
\hline 1 & Sebekia sp. & $35(41.17 \%)$ \\
2 & Nematodes & $6(7.05 \%)$ \\
& a.Ascaridoids & $1(1.17 \%)$ \\
\multirow{3}{*}{3} & b.Capillarioids & $3(3.52 \%)$ \\
& Trematodes & $31(36.47 \%)$ \\
& a. Proctocaecum gairhei & b.Exotidendridium sp. \\
\hline
\end{tabular}

During the study periods from July to December, Exotidendrium sp. (8\%) showed highest prevalence and Sebekia sp. (4\%) and Capillarioids (4\%) showed equal prevalence rate in the month of July. In August, Sebekia sp. (40.74\%) showed highest prevalence and then Exotidendrium sp. (33.33\%) followed by Ascaridoid (11.11\%). Similarly, Sebekia sp. (57.14\%) showed highest prevalence then Ascaridoids (14.28\%) followed by Exotidendrium sp. In October, Sebekia sp. (70\%) and Exotidendrium sp. (70\%) showed equal prevalence rate followed by Ascaridoids (20\%). In November and December, Sebekia sp. showed highest prevalence $80 \%$ and $100 \%$ respectively followed by Exotidendrium sp. $60 \%$ and $100 \%$ respectively (Table2). 
Prakash Mani Kumal and Mahendra Maharjan/Some Helminth Parasites from........

Table 2. Monthwise prevalence of helminth parasites of gharials

\begin{tabular}{|c|c|c|c|c|c|c|c|}
\hline \multirow[b]{2}{*}{ S.N. } & \multirow[b]{2}{*}{ Endoparasites } & \multicolumn{6}{|c|}{ Months } \\
\hline & & $\operatorname{Jul}(n=25)$ & $\operatorname{Aug}(n=27)$ & $\operatorname{Sept}(n=14)$ & $\operatorname{Oct}(n=10)$ & $\operatorname{Nov}(n=5)$ & $\operatorname{Dec}(n=4)$ \\
\hline 1 & Sebekia sp. & $1(4 \%)$ & $11(40.74 \%)$ & $8(57.14 \%)$ & $7(70 \%)$ & $4(80 \%)$ & $4(100 \%)$ \\
\hline 2 & Nematodes & & & & & & \\
\hline \multirow{5}{*}{3} & a.Ascaridoids & $0(0 \%)$ & $3(11.11 \%)$ & $2(14.28 \%)$ & $2(20 \%)$ & $0(0 \%)$ & $1(25 \%)$ \\
\hline & b.Capillarioids & $1(4 \%)$ & $0(0 \%)$ & $0(0 \%)$ & $0(0 \%)$ & $0(0 \%)$ & $0(0 \%)$ \\
\hline & Trematodes & & & & & & \\
\hline & gairhei. & $0(0 \%)$ & $0(0 \%)$ & $0(0 \%)$ & $0(0 \%)$ & $0(0 \%)$ & $3(75 \%)$ \\
\hline & b. Exotidendriumsp. & $2(8 \%)$ & $9(33.33 \%)$ & $6(42.85 \%)$ & $7(70 \%)$ & $3(60 \%)$ & $4(100 \%)$ \\
\hline
\end{tabular}

In the age groups 25-29 weeks, both highest and equal prevalence (100\%) were shown by Sebekia sp. and Exotidendrium sp. Similarly, in the age group 17-21 week again both Sebekia sp. and Exotidendrium sp. showed equal prevalence rate (70\%). However, no any parasitic infections $(0 \%)$ were observed in the age group 1-5 weeks (Table 3).

Table 3. Age wise prevalence of helminth parasites in gharials

\begin{tabular}{l|l|ll|ll}
\hline \multirow{2}{*}{$\begin{array}{l}\text { Age } \\
\text { groups(Weeks) }\end{array}$} & Sebekia sp. & Ascaridoids & Capillarioids & \multicolumn{2}{c}{ Proctocaecum } \\
gairhei & Exotidendrium sp \\
\hline $1-5(\mathrm{n}=4)$ & $0(0 \%)$ & $0(0 \%)$ & $0(0 \%)$ & $0(0 \%)$ & $0(0 \%)$ \\
$5-9(\mathrm{n}=24)$ & $1(4.16 \%)$ & $0(0 \%)$ & $1(4.16 \%)$ & $0(0 \%)$ & $2(8.33)$ \\
$9-13(\mathrm{n}=26)$ & $12(46.15 \%)$ & $3(11.53 \%)$ & $0(0 \%)$ & $0(0 \%)$ & $11(42.30 \%)$ \\
$13-17(\mathrm{n}=12)$ & $7(58.33 \%)$ & $0(0 \%)$ & $0(0 \%)$ & $0(0 \%)$ & $4(33.33 \%)$ \\
$17-21(\mathrm{n}=10)$ & $7(70 \%)$ & $2(20 \%)$ & $0(0 \%)$ & $0(0 \%)$ & $7(70 \%)$ \\
$21-25(\mathrm{n}=5)$ & $4(80 \%)$ & $0(0 \%)$ & $0(0 \%)$ & $0(0 \%)$ & $3(60 \%)$ \\
$25-29(\mathrm{n}=4)$ & $4(100 \%)$ & $1(25 \%)$ & $0(0 \%)$ & $3(75 \%)$ & $4(100 \%)$ \\
\hline
\end{tabular}

The overall prevalence of helminthes parasites in the present study was found to be $47.06 \%$ which is very greater $(17.36 \%)$ than the previous study (Gairhe 2007). This is the first report belonging to pentastomid parasite on gharials from Nepal. The pentastomid was identified as Sebekia sp. belonging to the family Sebekidae. The two new nematodes belonging to the family Ascarididae $(7.05 \%)$ and family Capillaridae $(1.17 \%)$ were also reported from this study. The capillariods were identified by the presence of characteristic egg with elongated polar poles. No such reports on capillarioid in gharial were found earlier from Nepal. Crocodilocapillaria longiovata is the only gastric capillariod and Paratrichosoma spp. are the skin capillarioids reported earlier (Ladds et al. 1995). However, they have no such serious path physiological effects on crocodiles. Similarly, the genus of Ascaridoids could not be confirmed because of the loss of its major portion during the exposure of intestine. The prevalence of Proctocaecum gairhei (5.84\%) was found higher than the prevalence $(3.52 \%)$ reported previously. Although, the trematode P. gairhei is not directly associated with gharial mortality they are responsible for enlargement and shortening of the duodenum and the gross thickening of the mucosa at the opening of the bile duct into the duodenum. Similarly, Exotidendrium sp. (36.47\%) was observed in the present study which is responsible for the pathological condition "Sphincter cap" in gharials. The pathological condition is characterized by a distinct whitish, blackish, yellowish and yellowish green or greenish granulomatous scab formed around colorectal orifice of the gharial hatchlings (Gairhe 2007). The two trematodes could not be identified.

Most of the helminths; Pentastomids, P. gairhei, Exotidendrium sp. and Ascardoid requires the intermediate host that is fish. So fish is the major source of helminthic infection. The gharials at the breeding center at Chitwan National Park are commonly fed with the fishes belonging to the families: Cyprinidae; Aspidopariamorar (commonly called Chepua), Barilius spp. (commonly called chepua), Labeo spp. (commonly called rohu), Bariliusbendelisis var. chedra 
(commonly called motia), Hypothalalmichtys spp. (commonly called silver carp) and Puntius spp. (commonly called sidhre) and family: Cichlidae; Tilapia spp. (commonly called tilapia). So, helminths infection in gharial hatchlings can be controlled by providing proper cold treated fishes and by giving them suitable antihelmintics.

\section{Acknowledgements}

Our sincere thanks go to the Department of National Park and Wildlife Conservation for research permission and University Grants Commission for research grant and to senior veterinary officer Dr. Kamal Prasad Gairhe, Chitwan National Park for proper guidance during the field studies.

\section{References}

Blair, D., D.R. Brooks, J. Puridie and L. Melville. 1988. Timonella absita $\mathrm{n}$. sp. (Digenea: Cryptogonimidae) from salt water crocodile (Crocodylus porosus Schndneider) from Australia. Canadian Journal of Zoology 66: 1763-1766.

Blair, D., J. Puridie and L. Melville. 1989. Renivermis crocodylii (Digenea: Exotidendriidae) n. g., n. sp. from the kidney of the salt water crocodile Crocodylus porosus in Australia. Systematic Parasitology 14(3): 181-186.

Christoffersen, M.L. and J.E. De Assis. 2013. A systematic monograph of the Recent Pentastomida, with a compilation of their hosts. Zoologische Mededelingen Leiden 87(1):29.

Gairhe, K.P. 2007. An investigation on the cause of mortality in captive gharial hatchlings at the Chitwan National Park, Nepal. M.V.Sc. Thesis. Institute of Agriculture and Animal Science, Tribhuvan University, Rampur, Nepal.

Huchzermeyer, F.W. 2003. Disease of farmed crocodiles and ostriches.Revue Scientific Et Technique-office International Des Epizooties 21(2): 265-276.

Junker, K. and J. Boomker 2006. A check-list of Pentastomid parasites of crocodilians and freshwater chelonians.Onderstepoort Journal of Veterinary Research 73: 27-36.

Junker, K. Wallace, A.J. Leslie and J. Boomker. 2006. Gastric nematodes of Nile crocodiles, Crocodylus niloticus Laurenti, 1768, in the Okavango River, Botswana. Onderstepoort Journal of Veterinary Research 73:111-114.

Ladds, P.W., H. Mangunwirjo, D. Sebayang and P.W. Daniels. 1995.Diseases in young farmed crocodiles in Irian Jaya. The Veterinary Record 136: 121-124.

Linstow, V.1906.Parasites from gharial (Gavialis gangeticus, Geoffr.).Journal of Asiatic Society of Bengal 2(7): 269271.
Moravec, F. 2001. Some helminth parasites from Morelet's crocodile, Crocodylus moreletii, from Yucatan, Mexico.Folia Parasitological 48:47-62.

Moravec, F. and F. Garibaldi. F. 2000. Huffmanelaparoni sp. n. (Nematoda: Trchosomoididae), a new parasite from the skin of swordfish Xiphiasgladius in the Ligurian sea (Western Mediterranean). Folia Parasitologica 47: 309-313.

Moravec, F., W.R. Kay and R.P. Hobbs. 2004. Micropleura australiensis n. sp. (Nematoda: Micropleruidae) from the body cavity of Crocodylus johnsoni in Western Australia. Journal of Parasitology 90(2): 322-326.

Narain, D. 1930. Neodiplostomum gavialis $\mathrm{n}$. sp. from the crocodile.Journal of Parasitology 16: 154-157.

Overstreet, R.M., T. Self and K.A. Vliet. 1985. The pentastomid Sebekia mississippiensis sp. n. in the American Alligator and Other Hosts. Proceedings of the Helminthological Society 52(2): 266-267.

Riley, J., G.F. Hill and F.W. Huchzermeyer. 1997. A description of Agema, new monotypic pentastomid genus Alofia Giglioli, 1922 and Sebekia Sambon, 1922 from a single Nile crocodile Crocodylus niloticus from Botswana. Systematic Parasitology 31: 221-238.

Rossin, M.A. and J.T. Timi. 2009. A new species of Paracapillarioides (Nematoda: Capillraiidae) parasitizing Nemadactylusbergi (Perciformes: Latridae) from the Argentine Sea. Folia Parsitologica 56(1): 37-40.

Shrivastava, C.B. 1981. Intraspecific variations in Exotidendrium gharialiiMehara, 1935 with a review of the family Exotidendriidae Mehra, 1935 status emended Shrivastava, 1977 (Trematoda: Digenea). Journal of Zoological Society of India 33 (1 and 2) 131-139.

Sprent, J.F., E.A. Mckeown and M. Cremin. 1998. Dujardinascaris spp. (Nematoda: Ascaridoidea) in Old World crocodilians. Systematic Parasitology 39: 209222.

Tellez, M. and J.P. Darand. 2011.Nematoda infection of the ventral scales of the American crocodile (Crocodylus acutus) and Morelet's crocodile (Crocodylus moreletii) in Southern Belize.Comparative Parasitology 78(2): 378-381.

Tkatch, V.V. and S.D. Synder 2010.Proctocaecum blairi sp. nov.(Digenea: Cryptogonimidae) from the freshwater crocodile, Crocodylus johnstoni in Northern Territory, Australia.ActaParasitologica 55(3): 240-244.

Tubangui, M.A. and V.A. Masilungan. 1936. Gastrointestinal helminth parasites of the American crocodile (Crocodylus acutus) in Southern Quintana Roo. Mexico Herpetological Conservation and Biology 4(3): 346-351.

Waddle, A.R., J.M. Kinsella, J.P. Ross and D.J. Forrester. 2009. Nematodes collected by gastric lavage from live American alligators, Alligator missipiensis in Florida. Journal of Parasitology 95(5): 1237-1238. 